Article

\title{
Mount Semeru Eruption on December 1, 2020: A volcanic ash cloud assessment using TIR imagery with 8.5-12.0 $\mu \mathrm{m}$ spectral bands
}

\section{Andri Wibowo ${ }^{1, *}$}

Abstract. Mount Semeru is one of the most active volcanoes in the Java Island. This article presents the results of observations and detections of volcanic ash cloud after Mt Semeru eruptions on 1 December 2020 at 01:23 AM. Volcanic ash cloud detection was conducted by analyzing thermal infrared (TIR) satellite images acquired by the NOAA-20 and SNPP with MODIS and VIIRS instruments. The TIR instruments have detected the presence of volcanic ash cloud. The results show increasing ash cloud brightness temperature (BT) from 240 to 270 Kelvin (K) several hours after eruptions. Increasing BT indicated the development of volcanic Cumulonimbus $(\mathrm{Cb})$ at lower altitude. Northeast movements of $270 \mathrm{~K}$ BT clouds were observed at 06:12 AM. Presences of volcanic $\mathrm{Cb}$ and $\mathrm{SO}_{2}$ were confirmed using IR bands of 12.0-10.8 $\mu \mathrm{m}, 11.0-8.5 \mu \mathrm{m}$ and $11.0 \mu \mathrm{m}$. This $\mathrm{Cb}$ cloud was observed moving northeast directions. The data acquired from the TIR imagery resulted from this study is thought be used in future to support and complement ground-based observations and detections of active volcanoes mainly in Java Island.
Keywords: ash, brightness temperature, Cumulonimbus, eruption, TIR, volcano

${ }^{1}$ U. o. Indonesia, West Java, 16424. Indonesia.

*Correspondence email:

paleobio2020@gmail.com

\section{Introduction}

A volcanic activity was characterized by its infrared region of the spectrum since this activity transfers heat from within the earth to the surface. This observed activity expressed in the thermal signature ranges from a fresh lava flow or an active lava lake to degassing surface or warmed crater-lake. Then observations emphasizing more on infrared region are useful when examining volcanic activity (Blackett 2017, Oppenheimer 1998). Volcano emits varied temperatures with fresh lava ranges of 1073-1273 Kelvin (K) with lava lake temperature can be at up to $1473 \mathrm{~K}$ and cooler active surfaces may reach $673 \mathrm{~K}$ (Fink et al. 2008, Oppenheimer \& Yirgu 2002). At these temperatures, the chief radiant emissions are in the thermal infrared (TIR), middle infrared (MIR) and shortwave infrared (SWIR) portions of the spectrum. The wavelength ranges of TIR, MIR and SWIR were 5.5-15.5 $\mu \mathrm{m}, 3.0-5.0 \mu \mathrm{m}$ and 1.0-2.5 $\mu \mathrm{m}$ correspondingly.

Various earth-observing satellites have sensors capable of observing these infrared emissions and as such are routinely used for volcanic observations. TIR was equipped in NASA Television Infrared Observation Satellite (TIROS) series launched in 1960. Since this time, TIR has observed wildfires to 
active volcanoes including 2006's eruption of Bezymianny volcano and Redoubt Volcano. In Indonesia, TIR observations have been used to determine lava extrusion rates and discriminating different types of lava dome activity of Merapi volcano in Java island (Carter et al. 2008, Carter et al. 2009, Carr et al. 2016, Wessels et al. 2013).

Infrared observation was pioneered by launches of satellite with its TIR instruments included NOAA with AVHRR, NASA GOES (geostationary satellite), Meteosat with SEVERI, NASA EOS with ASTER and MODIS (aqua and terra) and JPSS (NOAA 20 and SNPP), a joint satellite of NASA and NOAA with VIIRS instrument. SNPP is the first satellite mission to acquire a wide range of land, ocean, and atmospheric measurements while simultaneously addressing operational requirements for weather forecasting. VIIRS instrument has succeeded to detect ash cloud from Kamchatka eruption on 03/26/2015 based on false color imagery using combinations of $8.55 \mu \mathrm{m}, 10.76 \mu \mathrm{m}$ and $12.01 \mu \mathrm{m}$ spectral bands. It also has detected a thermal anomaly indicating increased volcanic activity at Mt Sakurajima, 14 hours before an eruption on August 18. Rapid developments of TIR instruments have an advantage for monitoring the volcano activities mainly in countries that located in the ring of fire including Indonesia.

Semeru is one of active volcano in Java island and has been reported erupted several times. The recent eruption was started at 01:23 AM on 12/01/2020. A visual observation has reported a volcanic ash released several times form the mountain. Regarding this situation, this paper aimed to assess the volcanic loads of recent Mt Semeru eruption using TIR imagery acquired by VIIRS instruments. Understanding active volcano in this study Mt Semeru is clearly useful in determining Mt Semeru's status and as such in predicting future activity. Making an early accurate assessment and detection remotely and at a safe distance is also notably advantageous.

\section{Methodology}

\subsection{Study area}

The study area was 3676 meter Mount Semeru (Mt) located in East Java. The geocoordinate of Mt Semeru were $8^{\circ} 6^{\prime} 28.8^{\prime \prime} \mathrm{S}$ and $112^{\circ} 55^{\prime} 12.0^{\prime \prime} \mathrm{E}$. The observation was made after the eruptions of Mt Semeru on December 1, 2020 (12/01/2020) started from 01:23 AM.

\subsection{TIR image acquisition}

The TIR image acquisition was following methods developed by Dubuisson et al. (2014), Ellrod et al. (2003), Pavolonis (2010) and Pavolonis et al. (2006, 2013, 2015, 2018). All TIR image were acquired from following satellites include GOES-EAST, GOES-WEST, NOAA-20 and SNPP with MODIS and VIIRS instruments. 


\subsubsection{VIIRS}

VIIRS stands for Visible Infrared Imaging Radiometer Suite, an instrument developed to collect visible and infrared imagery and global observations of land, atmosphere, cryosphere and oceans. This sensor is currently flying on the SNPP satellite mission. VIIRS provides critical environmental products about snow and ice cover, clouds, fog, aerosols, fire, smoke plumes, dust, vegetation health, phytoplankton abundance and chlorophyll. VIIRS has 22 channels ranging from $0.41 \mu \mathrm{m}$ to $12.01 \mu \mathrm{m}$ with 5 of these channels are high-resolution image bands or I-bands. Another 16 bands serve as moderate-resolution bands or M-bands. VIIRS also hosts a unique panchromatic day/night band.

\subsubsection{MODIS}

MODIS stands for Moderate Resolution Imaging Spectroradiometer is on-board the two polar orbiting satellites Aqua and Terra. Data acquisition of MODIS is in 36 channels with 3 channels in the infrared window $(8.6,11.0$ and $12.0 \mu \mathrm{m})$ at $1 \times 1 \mathrm{~km}^{2}$ spatial resolution. MODIS has viewing swath width of 2330 $\mathrm{km}$ and it capable of retrieving aerosol properties (Remer et al. 2005).

\subsubsection{Data acquisition}

Volcanic ash was assessed based on infrared channels (IR) at $11 \mu \mathrm{m}$ and combinations of 12.0-10.8 $\mu \mathrm{m}$ (red), 11.0-8.5 $\mu \mathrm{m}$ (green) and $11.0 \mu \mathrm{m}$ (blue). Measured variables to assess the volcanic ash are including ash height presented as brightness temperature/BT (K), presence of volcanic Cumulonimbus $(\mathrm{Cb}), \mathrm{SO}_{2}$ and reflectance (\%). Those variables were measured after eruption occurred.

\section{Results and Discussion}

Figure 2 shows the presence of volcanic ash detected using infrared (IR) of $10.8 \mu \mathrm{m}$ after eruption of Mt Semeru. The image was acquired at 05:24 AM and 06:12 AM on 12/1/2020 several hours after eruptions. The volcano ash was clearly detected at 06:12 AM while at early observation at 05:24 AM the ash was not occurred. At 06:12 AM, it was clear that the brightness temperature BT has higher value than value observed at 05:24 AM. Figure 3 presents the $10.8 \mu \mathrm{m}$ (BT) displayed with a color enhancement. Using color display, the coverage areas of volcanic ash were apparent and can be distinguished from non volcanic ash areas. The volcanic ash was observed covering and moving towards northeast area at 06:12 AM. Volcanic $\mathrm{Cb}$ and $\mathrm{SO}_{2}$ were presented in Figure 4 since as detected at 12.0$10.8 \mu \mathrm{m}, 11.0-8.5 \mu \mathrm{m}$ and $11.0 \mu \mathrm{m}$. $\mathrm{SO}_{2}$ was already observed at 05:24 $\mathrm{AM}$ and volcanic $\mathrm{Cb}$ was developed at 06:12 AM. This Cb cloud was observed moving northeast directions. The volcanic reflectance (\%) is displayed with a grayscale enhacement (Figure 5). Ash cloud at 06:12 AM was detected has high reflectance compared to the observation result at 05:24 AM. 

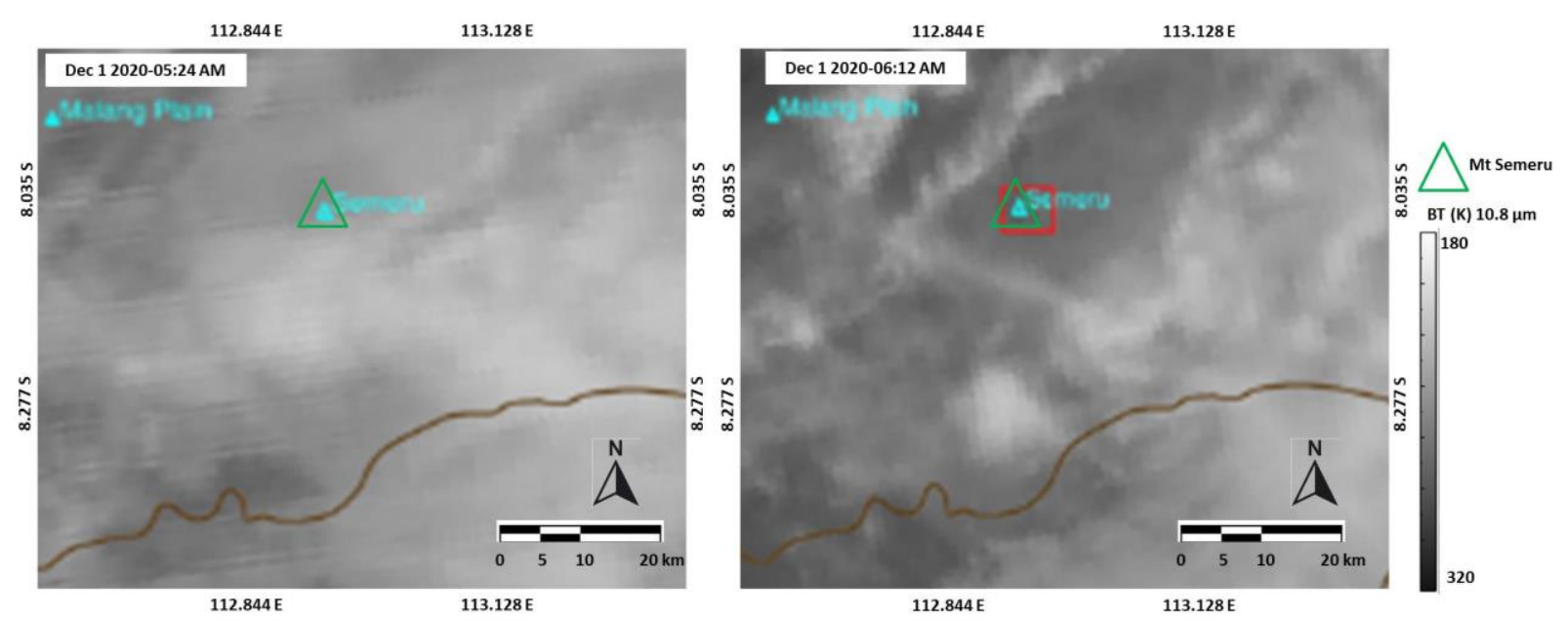

Figure 2. Infrared $(10.8 \mu \mathrm{m})$ images, with NOAA-20 and Suomi NPP VIIRS taken at 05:24 AM (left) and 06:12 AM (right) on December 1, 2020 in Mt Semeru
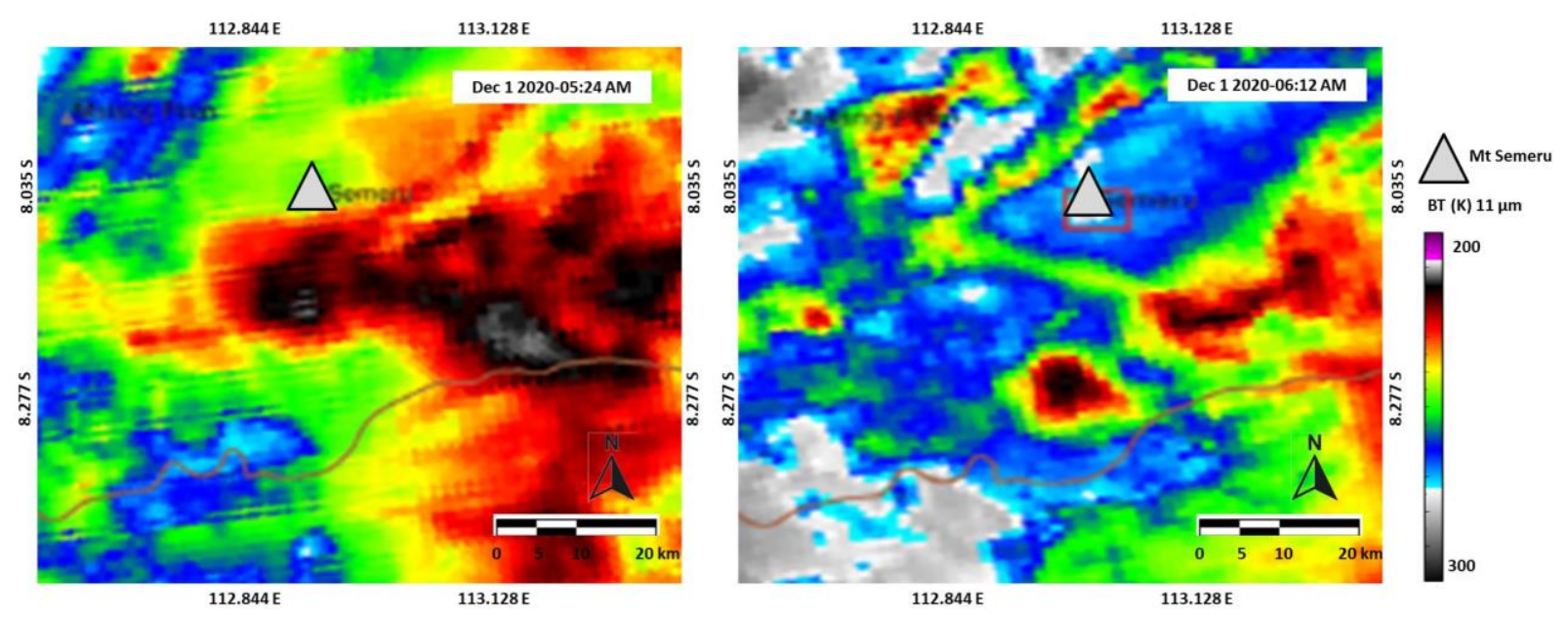

Figure 3. Color enhanced ( $11 \mu \mathrm{m})$ images, with NOAA-20 and Suomi NPP VIIRS taken at 05:24 AM (left) and 06:12 AM (right) on December 1, 2020 in Mt Semeru 

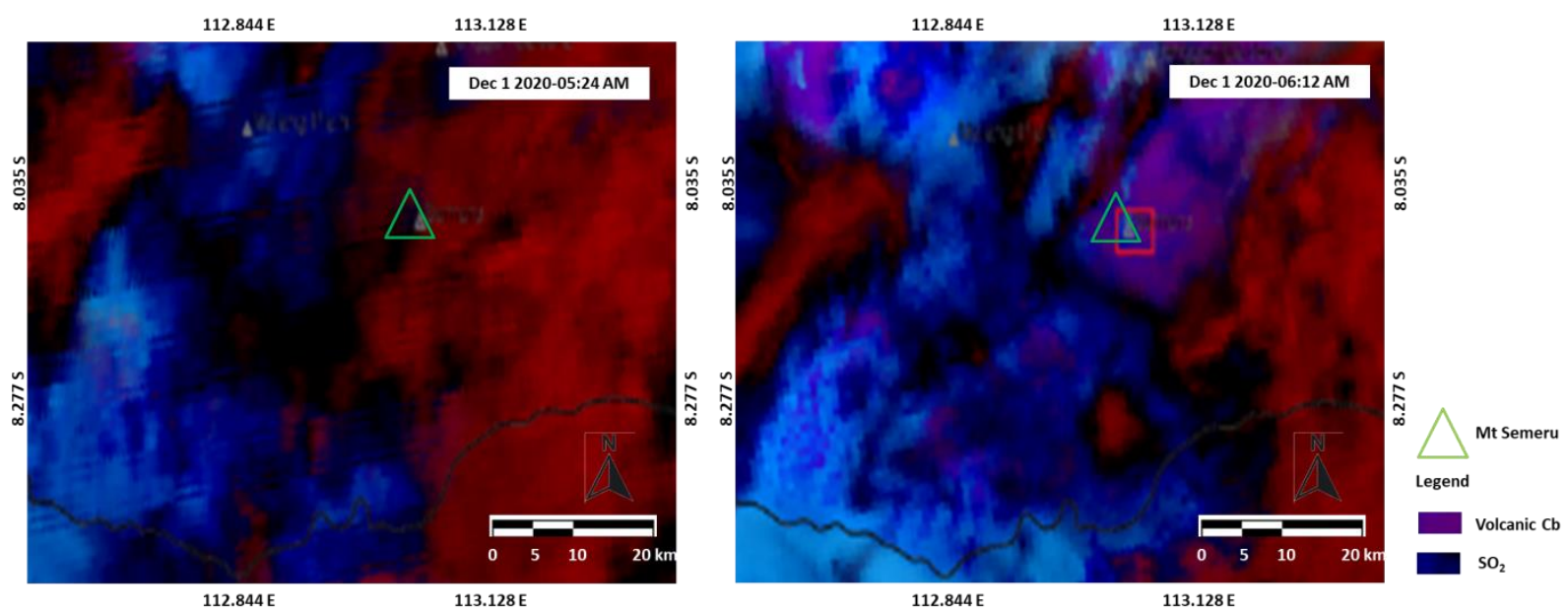

Figure 4. False color image 12.0-10.8 $\mu \mathrm{m}$ (red), 11.0-8.5 $\mu \mathrm{m}$ (green), $11.0 \mu \mathrm{m}$ (blue) , with NOAA-20 and Suomi NPP VIIRS volcanic $\mathrm{Cb}$ and $\mathrm{SO}_{2}$ products taken at 05:24 AM (left) and 06:12 AM (right) on December 1, 2020 in Mt Semeru
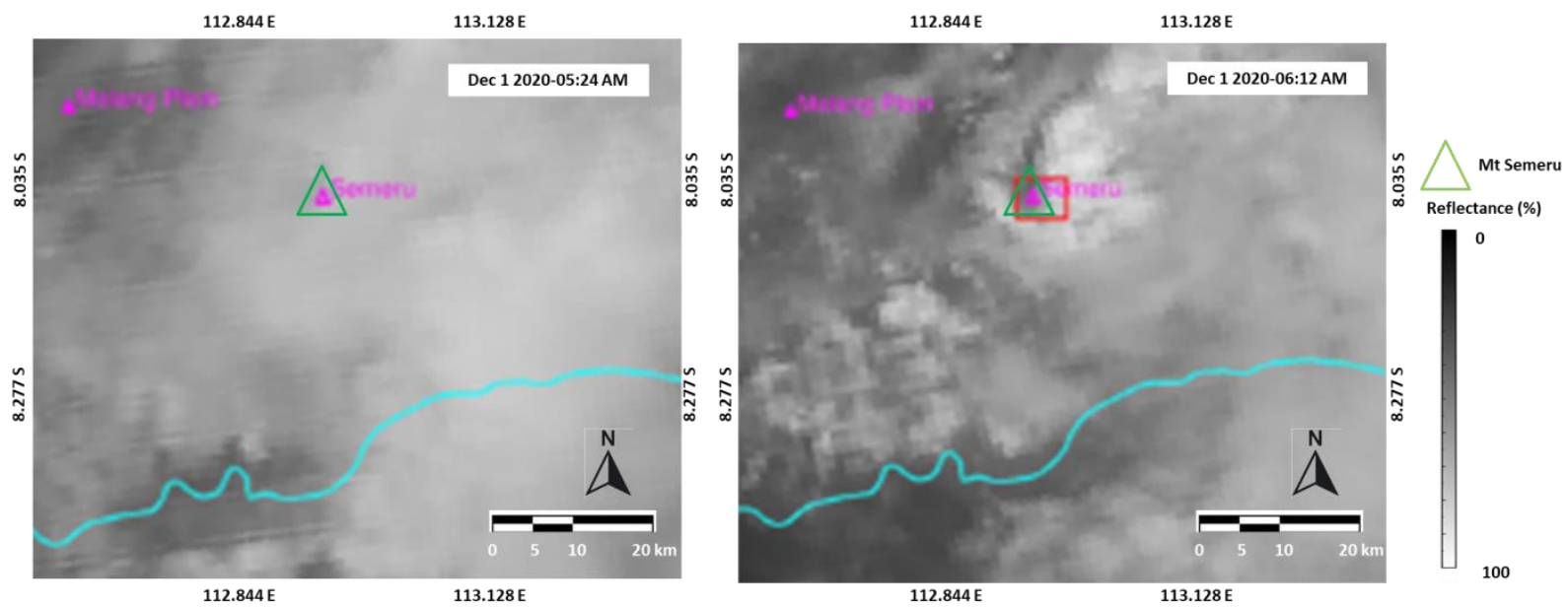

Figure 5. NOAA-20 and Suomi NPP VIIRS volcanic reflectance (\%) products taken at 05:24 AM (left) and 06:12 AM (right) on December 1, 2020 in Mt Semeru

The use of TIR instruments to observe thermal activities have received attentions including in Indonesia. Zubaidah et al. (2019) have utilized VIIRS Image for forest and land fire detections in Indonesia. The used VIIRS channel composite combinations included spectral bands of $1.61 \mu \mathrm{m}, 0.86$ $\mu \mathrm{m}, 0.44 \mu \mathrm{m}$ and $0.49 \mu \mathrm{m}, 0.44 \mu \mathrm{m}, 0.41 \mu \mathrm{m}$. The composite combinations have detected the presences of ash originated from forest fire in yellowish white and brownish white smoke. While the detection of $\mathrm{SO}_{2}$ contents emitted from Mt Sinabung volcano has been studied by de Laat et al. (2019) and Artaning et al. (2020) using the Sentinel 5P, TROPOMI and Himawari imageries. The Sentinel 5P has detected the presence and movements of $\mathrm{SO}_{2}$ contents from volcano crater to surrounding areas. Those studies have indicated that monitoring thermal objects mainly related to the volcanic eruptions are important. 
Despite growing studies on volcano ash monitoring, uses of VIIRS to monitor volcanic ash in Indonesia are still limited. Here, this study has provided empirical evidences of VIIRS uses to detect the volcanic ash presence, $\mathrm{BT}$, volcanic $\mathrm{Cb}, \mathrm{SO}_{2}$ and reflectance.

Brightness temperature (BT) value measured using VIIRS with $10.8 \mu \mathrm{m}$ is comparable with BT from other eruptions. BT of Mt Calbuco, Chile was $260 \mathrm{~K}$ and $270 \mathrm{~K}$ for Mt Tecapa, El Salvador. At 05:24 AM, Mt Semeru was covered by <220 K BT cloud, showing it was cloud at high altitude (Lin et al. 2011). While, cloud covers at 06:12 AM on the top Mt Semeru was replaced by $>260 \mathrm{~K}$ BT low altitude clouds indicating the presence of volcanic $\mathrm{Cb}$. $\mathrm{SO}_{2}$ was observed near $\mathrm{Mt}$ Semeru and overlapped with the cloud BT more than $220 \mathrm{~K}$ and less than $240 \mathrm{~K}$ indicating $\mathrm{SO}_{2}$ contained in high altitude atmosphere layers. According to $\mathrm{BT}$ values where $\mathrm{SO}_{2}$ was observed, stratosphere level is atmosphere layer that may contribute to $\mathrm{SO}_{2}$ through photolysis/oxidation of $\mathrm{SO}_{2}$.

One of TIR imagery advantages is its capability to detect the volcanic Cumulonimbus (Cb) cloud. This $\mathrm{Cb}$ is a convective cloud that can produce hazardous weather. A deep convection, such as a mature $\mathrm{Cb}$, is oftenly accompanied by rapidly changing weather on different spatial and temporal scale (Henken et al. 2009). $\mathrm{Cb}$ is a cloud that feeds directly from the heat and smoke of an intense fire. In this study, volcanic $\mathrm{Cb}$ was detected using VIIRS and it is comparable from other studies. Rosenfeld et al. (2014) reported VIIRS can provide a fine detail of the billowing volcanic $\mathrm{Cb}$ clouds that occur directly over the volcano crater. By using IR $10.7 \mu \mathrm{m}$ and SLIR combinations to assess Mt Montserrat eruption, cirrus, low cloud and an isolated deep convective cloud or $\mathrm{Cb}$ have been successfully distinguished.

\section{Conclusion}

Indonesia is one of countries that were located in the ring of fire and this situation has increased the volcanic activities. One of active volcano is Mt Semeru that recently has erupted on 12/01/2020. Eruption of a volcano may release volcanic ash leads to the development of volcanic $\mathrm{Cb}$ and $\mathrm{SO}_{2}$ releases. This study has provided evidences of volcanic ash detections using TIR imagery acquired from NOAA-20 and SNPP satellites with MODIS and VIIRS instruments. VIIRS sensors have detected a volcanic ash moving northeast at 06:12 AM. Simultaneously, volcanic $\mathrm{Cb}$ and $\mathrm{SO}_{2}$ contents were also observed. These results have strengthened the capability of TIR image to deliver accurate detection of volcanic ash properties.

Author correspondence: Andri Wibowo (paleobio2020@gmail.com)

\section{References}

Artaningh F, Anggraini A, Anjar S, Agustan. 2020. Pemantauan Konsentrasi Gas $\mathrm{SO}_{2}$ di Sekitar Gunung Sinabung Menggunakan Citra Satelit Sentinel-5 Precursor. 2. 32-39. 
Blackett M. 2017. An Overview of Infrared Remote Sensing of Volcanic Activity. J. Imaging. 3: 13.

Carter AJ, Girina O, Ramsey MS, Demyanchuk YV. 2008. ASTER and field observations of the 24 December 2006 eruption of Bezymianny volcano, Russia. Remote Sens. Environ. 112: 2569-2577.

Carter AJ, Ramsey MS. 2009. ASTER- and field-based observations at Bezymianny volcano: Focus on the 11 May 2007 pyroclastic flow deposit. Remote Sens. Environ. 113,: 2142-2151.

Carr BB, Clarke AB, Vanderkluysen L. 2016. The 2006 lava dome eruption of Merapi volcano (Indonesia): Detailed analysis using MODIS TIR. J. Volcanol. Geotherm. Res. 311: 60-71.

de Laat A, Vazquez-Navarro M, Theys N, Stammes P. 2019. Analysis of properties of the 19 February 2018 volcanic eruption of Mount Sinabung in S5P/TROPOMI and Himawari satellite data. Nat. Hazards Earth Syst. Sci. 20, 1203-1217.

Dubuisson P, Herbin H, Minvielle F, Compiègne M, Thieuleux F, Parol F, Pelon J. 2014. Remote sensing of volcanic ash plumes from thermal infrared: a case study analysis from SEVIRI, MODIS and IASI instruments. Atmos. Meas. Tech. 7: 359-371.

Ellrod G, Connell B, Hillger D. 2003. Improved detection of airborne volcanic ash using multispectral infrared satellite data. J. Geophys. Res. 108.

Fink JH, Srivastava A, Sylvester D, Blaauw D. 2008. Lava Flows and Domes: Emplacement Mechanisms and Hazard Implications. Springer: Berlin, Germany.

Friberg J, Martinsson BG, Sporre MK, Andersson SM, Brenninkmeijer CAM, Hermann M, van Velthoven PFJ, Zahn A. 2015. Influence of volcanic eruptions on midlatitude upper tropospheric aerosol and consequences for cirrus clouds. Earth and Space Science. 2: 285- 300.

Henken CC, Schmeits M, Wolters E, Roebeling R. 2009. Detection of Cb and TCu clouds using MSG-SEVIRI cloud physical properties and weather radar observations.

Lin Z, Liu J, Liu C. 2011 Satellite remote sensing of volcanic ash cloud in complicated meteorological conditions. Sci China Earth Sci. 54: 1789-1795.

Oppenheimer C, Yirgu G. 2002. Thermal imaging of an active lava lake: Erta 'ale volcano, Ethiopia. Int. J. Remote Sens. 23: 4777-4782.

Oppenheimer C. 1998. Review article: Volcanological applications of meteorological satellites. Int. J. Remote Sens. 19: 2829-2864.

Pavolonis M, Sieglaff J, Cintineo J. 2018. Automated detection explosive volcanic eruptions using satellite-derived cloud vertical growth rates. Earth and Space Science. 5(12): 903-928.

Pavolonis M, Sieglaff J, Cintineo J. 2015. Spectrally Enhanced Cloud Objects - A generalized framework for automated detection of volcanic ash and dust clouds using passive satellite measurements: 2 . 
Cloud object analysis and global application. Journal of Geophysical Research-Atmospheres. 120(15): 7842-7870.

Pavolonis M, Sieglaff J, Cintineo J. 2015. Spectrally Enhanced Cloud Objects - A generalized framework for automated detection of volcanic ash and dust clouds using passive satellite measurements: 1. Multispectral analysis. Journal of Geophysical Research-Atmospheres. 120(15): 7813-7841.

Pavolonis M, Heidinger A, Andrew K, Sieglaff J. 2013. Automated retrievals of volcanic ash and dust cloud properties from upwelling infrared measurements. Journal of Geophysical ResearchAtmospheres. 118 (3).

Pavolonis M. 2010. Advances in extracting cloud composition information from spaceborne infrared radiances - A robust alternative to brightness temperatures, part 1: Theory. Journal of Applied Meteorology and Climatology. 49(9): 1992-2012.

Pavolonis M, Feltz W, Heidinger A, Gallina GM. 2006. A daytime complement to the reverse absorption technique for improved automated detection of volcanic ash. Journal of Atmospheric and Oceanic Technology 23(11): 1422-1444.

Remer LA, Kaufman YJ, Tanré D, Mattoo S, Chu DA, Martins JV, Li RR, Ichoku C, Levy RC, Kleidman RG, Eck TF, Vermote E, Holben BN. 2005. The MODIS aerosol algorithm, products and validation, J. Atmos. Sci. 62: 947-973.

Rosenfeld D, Yu X, Zhu Y, Dai J, Xu X, Yue Z. 2014. High resolution (375 m) cloud microstructure as seen from the NPP/VIIRS Satellite imagery. Atmos. Chem. Phys. 14: 2479-2496.

Wessels RL, Vaughan RG, Patrick MR, Coombs ML. 2013. High-resolution satellite and airborne thermal infrared imaging of precursory unrest and 2009 eruption at redoubt volcano, Alaska. J. Volcanol. Geotherm. Res. 259: 248-269.

Zubaidah A, Sulma S, Suwarsono, Prasasti I. 2019. Pemanfaatan citra VIIRS untuk deteksi asap kebakaran hutan dan lahan di Indonesia. JPSL 9(4): 929-945. 